\title{
年輪解析による震災が樹木の成長に与える影響評価
}

\section{Assesment for Earthquake Disaster on Growth of Trees by Dendrochronological Method}

\author{
中村彰宏* 森本幸裕* \\ Akihiro NAKAMURA Yukihiro MORIMOTO
}

摘要 : 阪神・淡路大震災の液状化, 火災の影響が樹木の成長に与える影響を, 年輪解析から明らかに した。成長錐で被災した神戸市内に生育する樹木の, また震災の影響のなかった大阪府堺市に生育す る同一樹種のコアサンプルを採取し, 年輪幅の比較を行った。その結果, 液状化の生じた場所に生育 するクスノキ，クロマッ,アキニレには，液状化による長期的な成長量低下の影響はなかった。また 火災によって被災したクスノキには肥大成長量低下がみられたが，ヶヤキにはみられなかった。しか し被災の翌年に成長量の低下した樹木も，2 年後から成長量の增加がみられ, 震災の影響は短期的で あったと考えられた。

\section{1.はじめに}

1995 年 1 月 17 日に発生した兵庫県南部地震は, 家屋やビル, また上下水道や電気, ガスなどの生活基盤施設, 高速道路などの 交通インフラ施設に多大な被害を与え, 都市機能を麻痺させた。

一方, 地震が樹木に与えた直接的な影響は, 空洞化していた枝や 幹を折損しただけであることが震災後の緊急調査 ${ }^{14}$ によって明ら かにされている。植栽基盤の崩壊や家屋等の倒壊によって樹木は 二次的な被害を受けたが, 反対に樹木によって家屋やブロック垪 などの倒壊が防止されたことも確認されている。また公園に植栽 され被害のなかった樹木は，テントや物下し台の支えとして，照 明器具やブレーカーが設置され電柱代わりとしても利用された。 その他に，ッル植物によるモルタルや瓦などの落下防止，樹木に よる火災での延焼防止効果についても明らかにされている。火災 によって被災した樹木については, 赤外線ビデオを用いたアラカ シ樹冠面の活力度評価 ${ }^{11}$, 大国公園・新長田公園の震災から 1 年 半後のクスノキ，ケヤキなどの回復状況 ${ }^{12)}$ ，樹木の燃焼度と火元 距離との関係 ${ }^{8)}$ などが, 液状化によって被災した樹木については, 埋め立て地で震災直後の葉の展開などへの短期的な影響評価 ${ }^{20)}$ が 報告されている。

火災が樹木の成長に与える影響評価に関しては，林野火災の多 く発生するアメリカ, カナダ，オーストラリアなどで様々な研究 が行われ, 日本では他国ではみられない防火樹の研究が古くから 行われていることが紹介されている ${ }^{4)}$ 。欧米ではかつて, 森林で の炎を完全に排除する考えが, 可燃物の減少, 病害虫管理, 自 然植生の保全のため自然火や灭入れを受け入れる考え方に变化し た。それゆえ人工的な火入れによって植生管理がなされるように なり，火入れや自然火の影響を受けた樹木の処理判断基準の作成 のため, 欧米で火災が樹木の生育に与える影響評価に関する様々 な研究が行われ2), 日本では, 人工林での山火事による被害木の

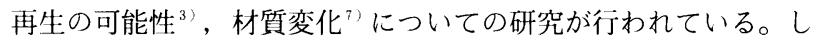
かし, 都市域での被災木に関しては, 関東大震災後の樹木の被害 状況とその回復力 ${ }^{1019}$ についての報告があるのみである。

アメリカの気象学者, A. E. Douglassによって 20 世紀初頭 に案出された ${ }^{13}$ 年輪年代学の解析手法は, 樹木の生育する自然環 境評価などの年輪気候学で，また建築物や遺跡から出土した木材 の年輪幅計測による伐採年の決定をするために考古学で利用され ている ${ }^{13)}$ 。またブナの年輪幅と結実豊作とエル・ニーニョの関係
について ${ }^{15)}$ ，針葉樹の年輪指数之前年および当年の季節毎の平均 気温，降水量，日照時間，年間積雪日数などの気象要素を用いた 重回帰分析による大気污染の影響評価 ${ }^{9}$ があり，幅広い分野で年 輪年代学は利用されている。

そこで本研究は，今後の都市災害発生時の被災木の処理，管理 方法決定のためのデー夕蓄積を目的として，阪神・淡路大震災で 生じた火災抢よび液状化が樹木の生育に与える影響について，年 輪解析から定量的評価を試みた。

\section{2. 調查地と調查方法}

(1) 調查地

阪神・淡路大震災で発生した液状化および火災の影響を受けた 神戸市内の 4 力所の公園を調査地とした。液状化の影響を受けた と考えられる神戸市東灘区中央区ポートアイランド南公園，火災 の影響を受けた長田区御蔵公園, 水笠西公園, 大国公園の 3 地点 の計 4 地点 (図-1） が被災地の調查地である。そして震災の影 響のない大阪府堺市の大阪府立大学構内を対照区とした。各調查 地点に植栽された，クスノキ，クロマッ，ケヤキ，アキニレを調 查対象木とした。表一 1 に調查地および災害の種類, 測定樹種, 測定本数, 平均樹高, 平均胸高直径を示す。測定は原則として孤

表 -1 調查地と測定樹種
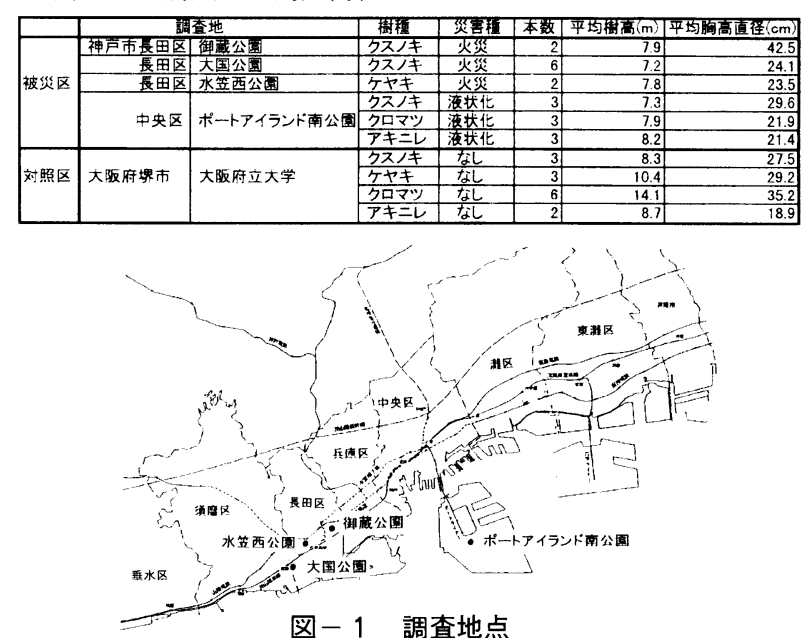

図-1 調查地点

*大阪府立大学農学部地域環境科学科 
立木を対象に行い，孤立木が存在しない場合には，群落内の樹冠 上部に位置する優勢木を対象とした。測定木の樹高は $5.9 \mathrm{~m}$ から $16.3 \mathrm{~m}$ の範囲であった。なお御蔵公園のクスノキは被災後に剪定 されたため, 胸高直径に比べ樹高が小さい。

\section{(2) 調査方法}

年輪測定用のコアサンプルは，各調查区に生育する樹木の樹幹 から成長錐を用いて採取した。採取部位は高さおよそ $1 \mathrm{~m} て ゙$ 枝の 存在しない部分とした。火災の被害を受けた樹木については, サ ンプル採取の方向が限定されるため，樹木 1 個体につき 3 方向で 採取した。神戸市内のサンプル採取は，1997年11月 8 日，1998 年 8 月 30 日，1998 年 10 月 19 日に, 対照区の大阪府立大学構内 では, 1997 年 11 月から 1998 年 12 月にかけて行った。樹木の樹 高, 胸高直径は 1998 年 10 月に測定した。ただし水笠西公園のケ ヤキのみ, 1997 年 11 月 8 日のデータである。火災によって被災 した御蔵公園，大国公園のクスノキについては，およそ $20 \mathrm{~cm} の$ 高度每に幹周長と形成層が焼け焦げて焼死した部位の長さの計測 を 1998 年 10 月 19 日に行った。なお，测定時は被災から 3 年半 以上が経過しており, 巻き込みのために焼け焦げた部分が減少し てると考えられるが，補正等は行わず測定值をそのまま用いた。 採取したコアサンプルは, カッターおよび剃刀で表面をなめらか にした後, 実体顕微鏡と目盛付き移動標本台で年輪幅を $0.001 \mathrm{~mm}$ の単位で測定した。そして採取した 3 方向の平均值を年輪幅とし て解析に用いた。しかし，偽年輪や節の影響があるものは計測せ ず，場所によっては 2 方向の平均値を利用した個体むある。

\section{3. 結果と考察}

\section{（1）年輪幅変動の特徵}

まず図ー 2 にポートアイランド南公園に植栽されたクスノキの 年輪幅の変動を示す。3 万向での年輪幅の絶対値は異なるが, 変 動パターンは㧍おむね同じ傾向であり，3 万向での平均化が問題 ないと考えられる。变動傾向は, 1976 年には $10 \mathrm{~mm}$ 近くの年輪幅 が，1981 年から 1988 年までは $1 \mathrm{~mm}$ 以下と低下している。この頃 に移植によって肥大成長量が減少し，1989 年から再び成長が回 復されてきたことが示されている。年輪解析には通常, 天然木や 植栽から長い年月の経過した樹木が用いられ，部位や個体間の差 を除去するために年輪幅変動に移動平均や, 多項式, 指数式, ス プライン関数などの傾向線をあてはめてる方法で規準化がなされ $3^{21)}$ 。しかし, 本研究では移植や震災といった非連続的なイベン トが発生しており，傾向線によるあてはめを行うことは不適切と 判断し，規準化を行わなかった。

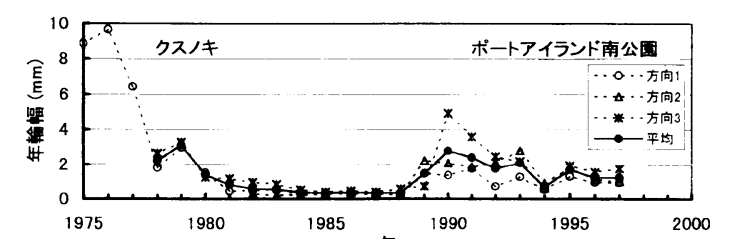

図ー2 ポートアイランド南公園のクスノキの年輪幅変動
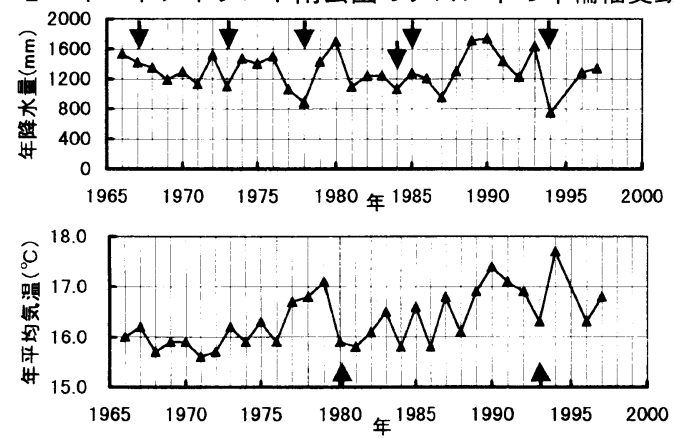

図－3 大阪管区気象台の年降水量(上段) と年平均気温(下段) (図中の矢印は, 上段 : 干害, 下段 : 冷害の発生した年)

\section{（2）平均温度および年降水量の変動}

図一 3 に神戸市から $30 \mathrm{~km}$ ，堺市から $13 \mathrm{~km}$ 離れた大阪管区気象 台の年降水量, 年平均気温の変化を示す。なお理科年表に記載さ れた近畿地方での干害と冷害の発生年むあわせて図示した。最近 では, 1993 年に冷害, 翌 1994 年には干害・酷暑, そして 1995 年に阪神・淡路大震災が発生した。この 3 年間は, 特徴的な気象 状況㧍よび震災の影響が発生している可能性があり, 1993 年か ら1995年にかけての年輪幅变動を中心として以下に考察を行った。 （3）液状化が樹木の年輪幅変動に与える影響

図一 4 上段に震災の影響を受けなかった大阪府立大学構内の対 照区での, 下段には液状化が生じたポートアイランド南公園での クスノキの年輪幅変動を示す。両調査区のすべての樹木で, 干害 の 1994 年には, 冷害の 1993 年の年輪幅変動よりも小さい。そし てポートアイランドの 1 本を除いたすべての樹木の 1995 年の年 輪幅は 1994 年より屯大きかった。また震災前後の肥大成長量の 比較のため, 震災前の 1992 年から 1994 年の 3 年間の平均年輪幅 と, 震災後の 1995 年から 1997 年の 3 年間の平均年輪幅の比率, $1995,1996,1997$ 各年の年輪幅と震災前 3 年間の平均年輪幅の比率 を表ー 2 に示す。対照区およびポートアイランドの震災前後の年 輪幅の比率はともに 1 前後であった。図一 5 に気象官署で測定さ れた 1992 年から 1997 年までの神戸と堺, そして図ー3に示した 大阪の年平均気温, 年降水量, 年積算日照時間を示す。いずれの 地点も瀬戸内海気候地域に属し, 距離も短いこともあり, 植物の 生育に大きな影響を与えると考えられるこの 3 項目の気象要素は 大差ないことがわかる。それゆえ, 神戸と堺において 1992 年か ら 1997 年までの樹木の肥大成長量は, 気象要素の差による影響 はほとんど受けていないと考えられ, 震災前後の年輪幅比率がほ ぼ同じであるため, 液状化がクスノキの成長に与えた影響はほと んどなかったと推測される。

図一，７の上段には対照区, 下段にはポートアイランド南公
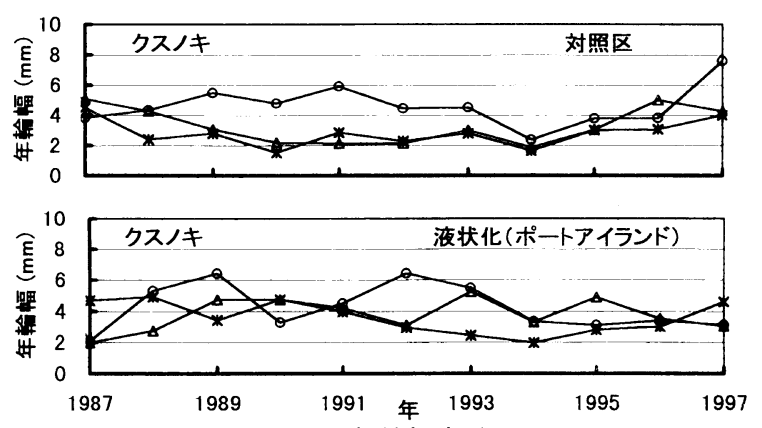

図一４クスノキの年輪幅変動

(上段 : 対照区, 下段：液状化の被災区）

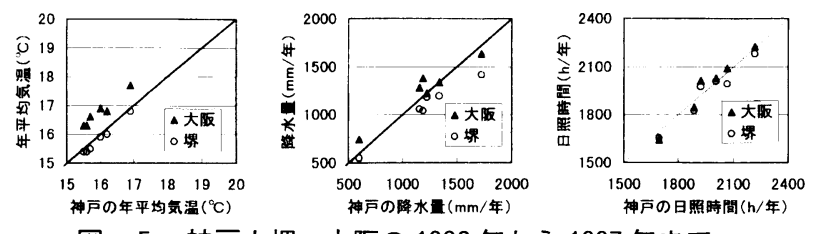

図－5 神戸之堺, 大阪の 1992 年から 1997 年まで の年間の平均気温, 降水量, 日照時間の関係

表 -2 震災前後の年輪幅の比率

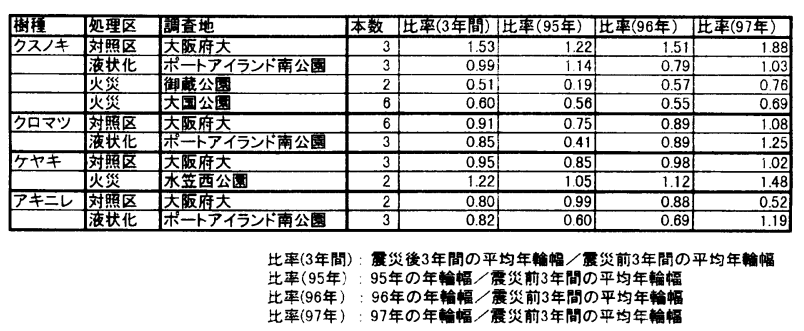


園でのクロマツおよびアキニレの年輪幅変動を示す。冷害および 干害の生じた 1993,1994 年とその翌年の 1995 年の年輪幅変動は, 対照区ではクスノキと同様に 1994 年に减少して 1995 年には増加 した。一方液状化の生じたポートアイランドにおけるクロマッで は, 1993 年から 1994 年への傾向が 1 本のみ異なっているが，他 はいずれも 1994 年に比べ震災の生じた 1995 年の年輪幅が小さかっ た。また表一 2 中の, ポートアイランドにおける 1995 年と震災 前 3 年間の年輪幅の比率が対照区の半分程度であり, クスノキや 対照区のクロマッとは異なる傾向であった。図 5 を考慮すると, 被災区で見られた成長量の低下は気象要素以外によると考えらる。 同公園内の震災直後の土壤の $\mathrm{EC}$ は $0.15 \sim 3.59 \mathrm{mS} / \mathrm{cm}$ 之高い場 所が存在し, 震災後の 1995 年 4 月 25 日には, $300 \mathrm{~mm}$ 程度の降雨 などの影響で $0.5 \mathrm{mS} / \mathrm{cm}$ と植物の生育に問題のないレベルに低 下したとの報告20)がある。しかし，震災直後にクロマッの観察を 行っておらず, 液状化が測定樹木に与えた影響は詳細にはわから ない。それゆえ，液状化によってクロマッの 1995 年の年輪幅が 小さくなったと結論づけることはできないが，液状化の影響がな かったと否定することもできない。震災の翌年である 1996 年以 降には, 年輪幅が震災前の 1994 年に比べ増加した。以上から, クロマッには液状化による一時的な成長量低下の可能性が残され るが，翌年にはその影響はなくなり，長期的な液状化の影響はな いことが明らかとなった。図ー7のアキニレの年輪幅では, 冷害
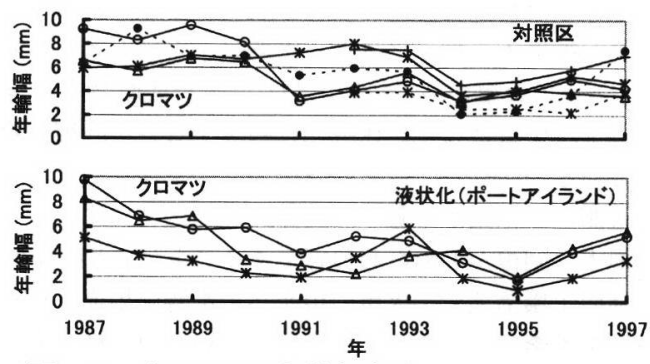

図－6 クロマツの年輪幅変動
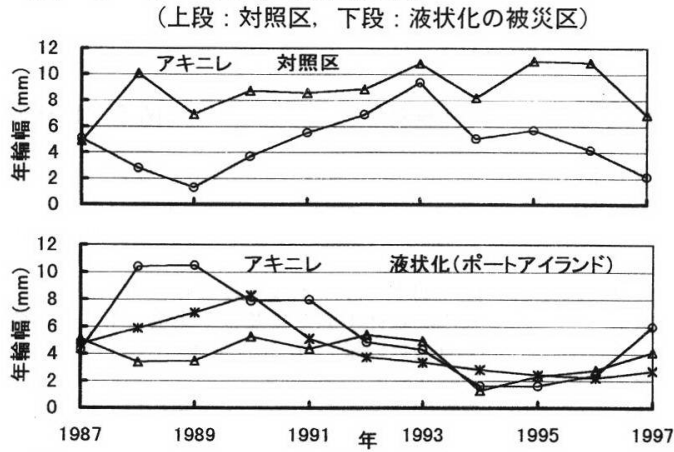

図ー 7 アキニレの年輪幅変動
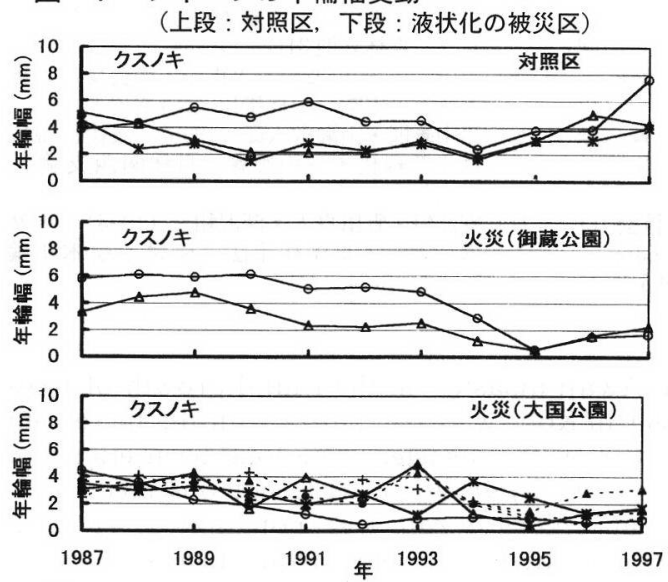

図一8 クスノキの年輪幅変動

(上段 : 対照区, 下段 : 火災の被災区)

と干害の生じた両年の傾向は, クスノキ, クロマッと同様であっ た。対照区では, 震災前後の年輪幅が大きく変動するが, 液状化 の被災区では変動が小さく, また, 1995 年の年輪幅の比率は対 照区に比べて小さいが, クロマッのように震災後に大きく年輪幅 が低下することはなかった。アキニレについては, 震災直後の 1995 年 5 月上旬まで液状化により同公園内で開葉は遅れたが,

5 月下旬には回復したと報告されている ${ }^{20)}$ 。このように開葉状態 が回復していることもあり, 年輪幅から液状化がアキニレの成長 に与えた影響は小さいと考えられる。

\section{（4）火災と年輪幅変動}

図-8 の上段には対照区，中段，下段には火災の影響を受けた 御蔵公園, 大国公園のクスノキの年輪幅変動を示す。上段の対照 区のクスノキは, 図一 4 上段と同一である。冷害と干害の発生し た 1993 年から 1994 年への年輪幅変動の傾向は, 両被災区でも対 照区とほぼ同じだった。被災区の 1995 年の年輪幅は, 大国公園 の 1 個体を除き, 1994 年の值に比べ低下した。特に御蔵公園の クスノキの年輪幅の低下は著しく, 1995 年の年輪幅は震災前 3 年間のおよそ $20 \%$ あっった。御蔵公園および大国公園のクスノ キの高度別の幹の周長之火災によって焼け焦げ，焼死した部位の 周長を図-9に, 表- 3 に高度 $5 \mathrm{~m}$ および $3 \mathrm{~m}$ までの幹周長の焼 け焦げ率 (図-9の焼焦長/幹周長) の平均値, 造園学会の緊急 報告書 ${ }^{14)}$ に記載された樹木番号および被害度, 樹高と幹部の焼け 焦げ範囲 (最小高と最大高), 1995 年と震災前 3 年間の年輪幅の 比率を示す。御蔵公園の樹木は, 現存する幹の最上部までが焼け 焦げ, 地上 $5 \mathrm{~m}$ までの平均焼け焦げ率は $50 \%$ 以上と大きい（写 真 -1 )。一方大国公園の樹木は, 幹の一部が焼け焦げ, 御蔵公 園に比べ焼け焦げ率が小さい。図-10に高度 $5 \mathrm{~m}$ までの幹の焼 け焦げ率と 1995 年と震災前 3 年間の年輪幅の比率の関係を示す。
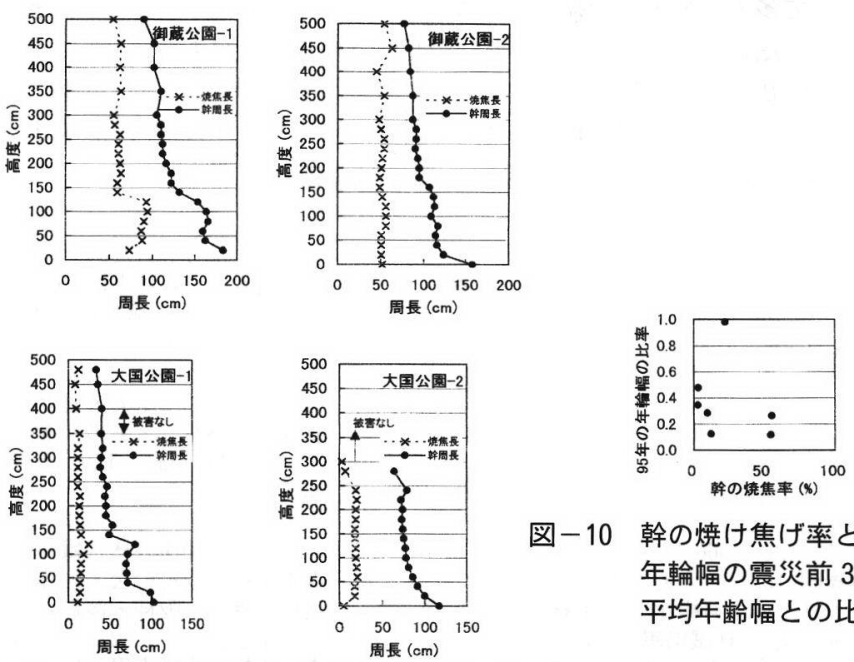

図ー10 幹の焼け焦げ率と95年の 年輪幅の震災前 3 年間の 平均年齢幅との比率

図-9 被災木の高度別の幹周長と火災によって 焼け焦げた部位の長さ

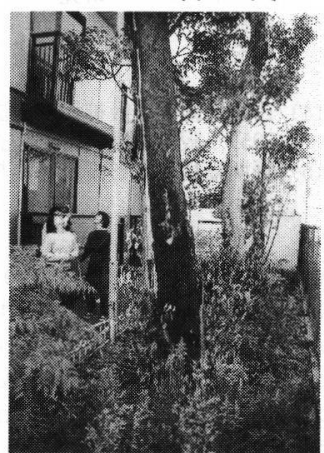

写真ー 1 火災の被害を受けた 御蔵公園のクスノキ

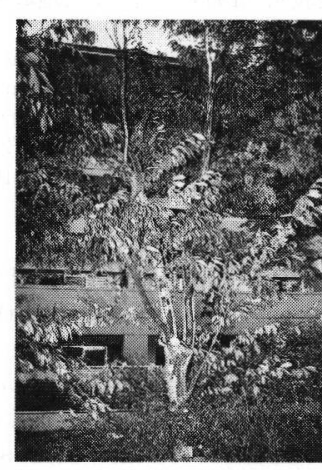

写真ー 2 火災の被害を受けた 水笠西公園のケヤキ 
表一 3 火災被災区のクスノキ幹部の焼け焦げ率と 95年の年輪幅の比率

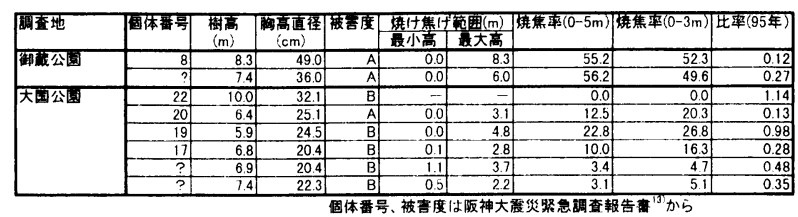

サンプル数が少ないため，明瞭な傾向は見られなかったが，焼け 焦げ率が抢よそ15\% 55\%の個体で，被災直後の年輪幅が被災 前の 20\%程度に減少していることがわかる。

図-11 に対照区と火災の影響を受けた水笠西公園のケヤキの 年輪幅変動を示す。対照区での 1995 年のそれ以前の年輪幅との 比率は，1 以下であるが，被災区では 1 以上であり，年輪幅が増 加したことを示している。しかし写真－2にみられるように，幹 周の半分程度が焼死しているため, 活動している形成層部分によ る断面積増加量は震災前よりは低下していると考えられる。

Ducrey $^{2}$ らは, 冬季に Aleppo pine 幹部のヒーター加熱実 験とその後のモニタリングにより，幹周 100\%の加熱処理区では $1 \sim 5$ 月後に枯死し, 枯死直前の数日まで夜明け前の水ポテン シャル, 純光合成速度, 気孔コンダクタンスが対照区と差がない ことを示した。また幹周で 38〜 78\%加熱処理をした樹木では, 被害を受けなかった形成層部分の活動により上述の生理特性は対 照区之有意な差はなく，この樹種の耐火性が大きいことも示した。

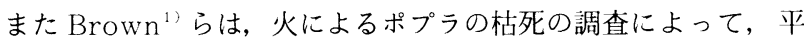
均で幹周 75\%以上が焦げた個体が枯死すると報告している。御 蔵公園のクスノキは，広葉樹で萌芽性が強いことも影響したため か，高度 $5 \mathrm{~m}$ までの幹部が周長で $50 \%$ 以上焼け焦げるとの山火 事勇18)に比べて多大な被害を受けたにもかかわらず生育を続けて いる。水笠西公園のケヤキも幹部の半分程度が焼け焦げたにもか かわらず年輪幅の減少がみられなかった。これらから两種の耐火 性が大きいことが考えら, 関東大震災後の調査で得られた中程度 の耐火性との結果 ${ }^{19)}$ と矛盾しない。Ryan ${ }^{16)} ら は 7$ 種の針葉樹に

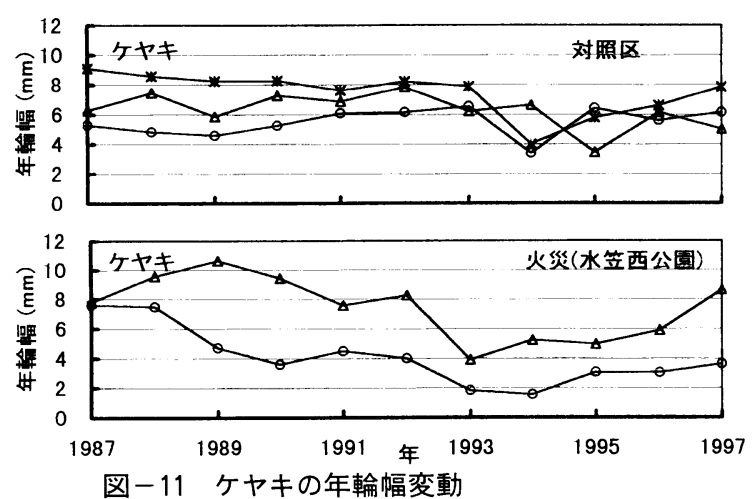

(上段 : 対照区, 下段 : 火災の被災区)

ついて，火災による樹木個体の枯死率は，樹皮の厚さ之樹幹の焼 死率の関数で良好に推定できることを示している。図一-9におい て幹部の焼け焦げ率と年輪幅の比率の相関がみられなかったが, これはサンプル数が少なかったこと，本研究では行っていない樹 冠の被害評価を考慮していないためだと思われる。山火事では, 林床に堆積した落葉落枝が可燃物となって地表面が高温となるこ とがあり ${ }^{5)}$ ，また地表面の細根が焼失および焼死する ${ }^{17)}$ 。大国公 園および御蔵公園の火災後の写真 ${ }^{(4)}$ からは, 両公園の被災樹木周 辺に落葉落枝は見られないため，地表面温度は高温とならず，ま た地中深くなるにしたがって急激に温度は低下するといわれてい るため ${ }^{5}$ ，火災が被災木の根系に与えた影響は小さいと考えられ る。Harrington ${ }^{6)}$ は火事の被災時期に関し，光合成産物の貯留 量の多少によって，生育期に比べ休眠期に被災する方が回復が良 いことを示している。

本研究の年輪測定の結果から阪神・淡路大震災において火災の 影響を受けた樹木の回復がおおむね良好であることが示されるが， これらは，森林の土壌構造や山火事の根系への影響の相違，樹種 特性, 被災時期が冬季であったことが影響していた可能性が考え られる。

\section{引用文献}

1) Brown, J.K. and DeByle, N.V. (1987): Fire damage, mortality, and suckering in aspen: Can. J. For. Res. Vol.17, 1100 1109

2) Ducrey, M., Duhoux, F., Huc, R., and Rigolot, E. (1996): The ecophysiological and growth responses of Aleppo pine (Pinus halepensis) to controlled heating applied to the base of trunk: Can. J. For. Res. Vol.26, 1366-1374

3 ）後藤義明(1987）: 火災や寒害をうけたスギ, 七ノキ林の再生可能性（スギ林の火災枯死 率の推定法): 林試場報 $277,6-7$

4 ) 後藤義明・大谷義一 (1988)：森林火災の概 念之研究動问：森林立地 (2)，41-56

5 ) 後藤義明 (1998)：山火事と地域環境：森林 科学 $24,14-21$

6 ) Harrington, M. G. (1993): Predicting Pinus ponderosa mortality from dormant season and growing season fire injury: Int. J. Wildl. Fire Vol.3 No.2, 65-72

7 ）長谷川浩一・佐々朋幸（1993）：山火事（地
表火）によってもたらされるスギ樹幹基部 の材質变化：森林立地 35(2)，1-9

8 ) 管藤武 (1996): 阪神淡路大震災の火災之樹 木の燃焼（防火性）亡復活（耐火性）：林 業技術 Vol.651，19-22

9 ) 加藤輝隆 - 加須屋実 - 鏡森定信 - 河野昭一・ 狐塚寞(1988)：スギの年輪幅に及ぼす大気 污染の影響評価（I）：大気污染学会誌 23(6), 311-319

10）河田本・柳田由蔵（1923）: 火災卜樹林並ビ 二樹木卜/関係: 林試輯報 特別号, 1-33

11）森本幸裕・中村彰宏・佐藤治雄（1996）：街 路樹の機能上阪神・淡路大震災：国際交通 安全学会誌 Vol.22 No.1, 49-56

12）森本幸裕・木田幸男（1996）：祳災からの回

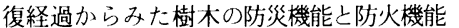
ランドスケープ研究 Vol60 No.2, 111-112

13）奈良国立文化財研究所編 $(1990)$ ：年輪に歴 史を読む一日本に戈ける古年輪学の成立一： 同朋舎, $195 \mathrm{pp}$

14）日本造園学会阪神大震災調査特別委員会（1 995）：阪神大震災緊急調查報告書, $163 \mathrm{pp}$

15）野堀嘉裕・尾形俊成・高橋教夫（1995）：ブ
ナ年輪変動とェルニーニョの関係：日林論 106, 409-410

16) Ryan, K.C. and Reinhardt, E.D. (1988): Predicting postfire mortality of seven western conifers: Can. J. For. Res. 18, 1291-1297

17）佐々朋幸・佐々木茂・後藤和秋（1988）：山 火事が森林生態系に及ぼす影響（Ｉ）－焼 失有機物の量と根への被害一：日林論 99 , $167-168$

18）佐々朋幸・長谷川浩一・後藤和秋（1989）： 地表火による樹幹の焼け焦げ程度からみた 樹体の生死将来予測法確立への事例解析 被災 2 年後のスギ壮龄木健全度調查結果よ り一: 森林立地 31(2)，46-54

19）田中八百八（1923）: 大正の大地震及び大火 と帝都の樹園：山林輯報 臨時増刊,1-29

20）田中義則・山瀬敬太郎（1996）：液状化現象 による緑化木への影響：日林関西支論 Vol.5, 173-174

21）安江恒・野田真人・深沢和三 (1993)：天然 木に戈ける標準化手法の検討：樹木年輪 Vol.6, 18-24

Summary: The influences of fire and liquefaction caused by the Hanshin-Awaji disaster on the radial growth of trees were investigated. Ring widths of trees which were suffered by the disaster in Kobe were compared with the increment cores of trees of same species planted in Sakai City which were not sufferd from the disaster. The long term effects of liquefaction on growth of Cinnamomum camphora, Pinus thunbergii, Ulmas parvifolia were not observed. Fire decreased the ring widths of Cinammomum camphora after the disaster, but Zelkova serrata were not affected. The ring widths of trees which were suffered from fire or liquefaction were increased after two years from disaster, so the influences of fire and liquefaction do not remained for long period in Kobe City. 